\title{
On the Production of Dwarf Male Prothalli in Sporangia of Todea. ${ }^{1}$
}

\author{
BY \\ L. A. BOODLE, F.L.S., \\ Assistant, Royal Botanic Gardens, Kerv.
}

With Plate XVI.

W HEN examining sporangia of filmy species ${ }^{2}$ of Todea, a few years ago, I was surprised to find that closed sporangia attached to the leaf sometimes contained antheridia, owing to the spores having germinated and at once formed the male organs. This appeared so interesting that I attempted by a series of experiments (in I904 and I905) to gain some light on the cause of this precocious formation of sexual organs. Such results as were obtained did not lead very far towards an explanation of the phenomenon, though determining its relation to certain conditions. Publication ${ }^{3}$ was consequently postponed awaiting an opportunity of making further experiments. As, however, the phenomenon itself is of some importance, it seems advisable not to delay longer, but to place the observation on record with the results obtained, in the hope that other botanists may carry the matter further.

Todea Fraseri, Hook. et Grev. and T. hymenophylloides, Rich. et Less. were the species on which most of the observations were made, and, of these, $T$. Fraseri was found to be more ready to form intrasporangial antheridia. The mature sporangia are dark green owing to the dense chlorophyllous contents of the ripe spores, and ultimately appear greenish black by reflected light. It is in these very dark sporangia after they have passed maturity that antheridia are sometimes to be found. An example is given in Pl. XVI, Fig. I, which is from a microtome-section of a closed ${ }^{4}$ sporangium obtained from a fertile leaf of $T$. Fraseri. The spores are seen to have germinated and produced antheridia, eight of which are visible in this section. The details are better seen in Fig. 2, which represents the

1 From the Jodrell Laboratory, Royal Botanic Gardens, Kew.

2 The filmy species of Todea, Willd. (cf. Synopsis Filicum) form the genus Leptopteris of Presl.

${ }^{3}$ A short preliminary account was read before Section $\mathrm{K}$ of the British Association at Cambridge in 1904 .

- The injuries in the wall of the sporangium are due to the dragging of the razor.

[Annals of Botany, Vol. XXII. No. LXXXVI. April, 1908.] 
product of germination of a single spore in the same sporangium. The antheridium at the top contains numerous sperm-cells $(s$.$) , and is borne by$ an extremely reduced gametophyte, enclosed at the base by the ruptured exosporium (e.). Below the cavity of the antheridium there are only five cells. Of these the upper two may be regarded as forming the basal part or stalk of the antheridium, thus leaving only three cells for the prothallus. No rhizoid-cell is present in this specimen.

In the sporangium shown in Fig. I, nearly all the spores had produced dwarf male prothalli similar to Fig. 2, but in other cases the number of male prothalli in a sporangium was usually small. For a typical case, in which intrasporangial germination has taken place and advanced sufficiently, the contents of the sporangium may be described as follows: a few prothalli of about three cells and usually with a rhizoid; a few prothalli bearing antheridia, and nearly always without developed rhizoids; the majority of the spores showing no signs of germination. In sporangia in which only two or three spores had germinated, the young prothalli had no antheridia, and usually bore rhizoids. From the presence of rhizoids, and from comparison with experimental cultures, in which germination has not advanced very far, one may infer that the prothalli first formed are not those which finally bear antheridia.

The preceding remarks apply to sporangia attached to the leaf, the observations having been made on two plants of $T$. Fraseri growing in the Filmy Fern House at $\mathrm{Kew}^{1}$. In this species the production of antheridia inside sporangia attached to the leaf was observed in four different years, but was not seen on living plants of $T$.hymenophylloides, $T$. superba, Col. or T. Moorei, Baker. A few young prothalli were several times found in T. hymenophylloides, and occasionally in the two other species, among the spores in closed sporangia, but these prothalli did not bear antheridia, and were usually not far enough advanced to do so.

A short description of experiments may now be given. Pinnae or pinnules bearing dark green sporangia were removed from the living plant, and, while kept damp, were examined under a low power of the microscope, to see that none of the sporangia had burst ${ }^{2}$. The contents of some of the oldest sporangia were then examined, and, if germination had not begun in these, the other sporangia were taken as suitable for experiment.

The essential feature in a number of the experiments consisted in keeping free spores and closed sporangia under similar conditions, and then comparing the mode of germination of the spores in the two cases. The free spores were taken from sporangia on the same leaf (usually on the

1 At the time at which some of these observations were made, the temperature of this house was usually kept between $10^{\circ}$ and $13^{\circ} \mathrm{C}$., but the best cases of intrasporangial germination were found in the warmer months, when the temperature was often considerably higher.

${ }^{2}$ When damp, sporangia, which have dehisced, may close again sufficiently to render close examination necessary. 
same pinnule) as the closed sporangia used in the same experiment, and the two cultures were placed side by side in a greenhouse, Petri-dishes being used in most cases. The temperature of the greenhouse varied considerably, but during the day-time, in some or most of the experiments, was usually between $16^{\circ}$ and $21^{\circ} \mathrm{C}$. One experiment including several cultures was set up as follows. Free spores were kept (I) on damp blotting-paper, (2) on damp sand, (3) immersed in water in a watch-glass. Three parallel cultures were made, using detached closed sporangia instead of spores. These were all exposed to daylight, and a similar set of six cultures was kept in darkness (in a light-tight box). To these were added pinnae bearing sporangia, and placed on damp blotting-paper in light and in the dark. This experiment was carried out both in $T$. Fraseri and in T. hymenophylloides, and some of the pairs of cultures were repeated two or three times.

The general result obtained was that dwarf male prothalli with antheridia were found in several of the sporangia, but were never produced by the germination of free spores. From an examination of the contents of the sporangia, it was evident that, under the conditions of the experiments, a certain number of dwarf prothalli with antheridia were formed in the sporangium whenever the germinative power of the spores was sufficiently strong, and the culture could be kept healthy long enough. Their formation is thus connected with germination inside the closed sporangium, and this again is due to excessive dampness, which prevents the sporangium from dehiscing when mature. This was shown by uncovering a Petri-dish containing a pinna with sporangia on damp blotting-paper. A few minutes' exposure to dry air, if the culture was not too damp, was sufficient to cause normal dehiscence of several sporangia.

Figs. 3 and 4 are examples of dwarf gametophytes from closed sporangia, which had been kept damp in the light for twenty-one days. They are shown in optical section, with the cell-contents omitted (as in most of the figures), $a$. being the cavity of the antheridium. It will be seen that Fig. 3 is very similar to Fig. 2, described above, but differs in the presence of a rhizoid-cell ( $r . c$.$) , while Fig. 4$ has no rhizoid-cell, and is exceptional in having a rudiment of a lateral branch (l.), which, from comparison with another specimen, may have been destined to form a second antheridium.

Sporangia which fail to dehisce behave alike when exposed to light, whether they remain attached to the living plant, or to a pinnule kept damp on blotting-paper, or whether they are detached and similarly treated; at any rate no marked difference in the germination of the spores was noticed. Under favourable conditions a number of spores germinate, and some of them produce dwarf prothalli and antheridia ${ }^{1}$. The prothalli

1 In the case of sporangia immersed in water, germination was usually not very satisfactory, perhaps owing to defective aeration. 
appear to be incapable of bursting the wall of the sporangium, and they and the ungerminated spores ultimately die. Several attempts were made to obtain motile spermatozoids, but always failed. Sporangia were ruptured, and the contents examined in water, but usually any antheridia present refused to burst. Once or twice an antheridium was seen to dehisce, and the spermatocytes passed out, but the spermatozoids did not even uncoil.

Free spores, when germinated in the light, formed normal prothalli (see Fig. II), which, however, showed some differences according to the nature of the culture. On sand the primary rhizoid was usually long; on damp blotting-paper it was often well developed, but sometimes rudimentary or absent ; in water it was often rudimentary or absent, though occasionally fairly well developed. On blotting-paper reduction of most of the rhizoids was sometimes observed, and appeared to be caused by wetness of the culture. In water the prothallus tended to be more rounded, or thicker and less elongated, than on sand or blotting-paper.

In most cases free spores were found to germinate very readily in the light. Direct sunlight was kept off the cultures by a screen, and a blind on the top of the greenhouse reduced the light. From an experiment in which the light was further reduced and growth less rapid, one may assume that, if the illumination was above the optimum, it was not far above it ${ }^{1}$.

The spores are also capable of germination in darkness, but growth is slower than in light, and finally comes to a standstill. Figs. 5 and 6 are from two cultures of $T$. Fraseri after twenty-six days in darkness. Fig. 5 is a prothallus and antheridium from a closed sporangium, and Fig. 6 is a prothallus formed by the germination of a free spore. In Fig. 5 the sperm-cells (s.) are shown in the antheridium, and the greater part of the prothallus is enclosed in the exosporium $(e$.$) , so that it cannot be seen how$ many cells are present. This experiment shows that light is not necessary to the production of antheridia inside the sporangium. Gametophytes with antheridia, similar to Fig. 5, were formed in several sporangia in darkness, and, just as in cultures in the light, they were accompanied by some small prothalli without antheridia. A rather common feature in sporangia kept in darkness is the presence of prothalli with abortive antheridia, and what may be described as vegetative transformations of young antheridia. These will be referred to again later. Fig. 7 is one of the most reduced gametophytes met with, and is from a sporangium after twenty-two days in darkness. The antheridium has a very small cavity $(a$.$) , below which there$ are only two cells, one probably representing the stalk, and the other the prothallus.

In T. hymenophylloides the germination of the spores and the growth of the prothallus are less rapid than in $T$. Fraseri under the conditions of

${ }^{1}$ Heim ('96, p. 354) found that for certain Fern-prothalli the strongest growth took place in daylight (Munich) reduced by 20-25 per cent. 
the experiments, and it is probably in consequence of this, that fully formed antheridia were only rarely found in cultures of closed sporangia of T. hymenophylloides. In several cases the cultures became unhealthy before germination was sufficiently far advanced. Figs. 8 and 9 are prothalli from a closed sporangium after thirty-two days in the light. In Fig. 9, no antheridium has been formed, while in Fig. 8 an abnormal antheridium, in which the cavity $(a$.$) contains chlorophyll, is borne by a very rudimentary$ prothallus. The presence of a rhizoid $(r$. $)$ in this type of prothallus is not common. In Fig. Io (also from a closed sporangium of T. hymenophylloides) the form of the cells indicates that the prothallium had made an abortive attempt to form an antheridium. Several similar examples were seen in $T$. hymenophylloides in closed sporangia. In these, two or more celldivisions had taken place, cutting off cells similar to those which normally go to form the antheridium, but the cells generally retained their chlorophyll, and sometimes became enlarged.

Examples of well-advanced prothalli grown from free spores on blotting-paper in the light are given in Figs. I I and I2. Fig. II is from a spore of $T$. Fraseri after thirty-six days. The rhizoid $(r)$ is rudimentary in this specimen, and, as often occurs when the rhizoid is reduced, its wall is thickened in the form of a cap at the apex. Fig. 12 is from a spore of $T$. hymenophylloides after thirty-two days, and may be compared with Figs. 8 and 9, which are prothalli from a sporangium in a culture of the same age.

Some experiments of a different kind may now be referred to. Firstly, germination of free spores in distilled water and tap-water ${ }^{1}$ was compared, and it was found that the spores germinated more rapidly in distilled water. Figs. 13 and $\mathrm{I}_{4}$ are from cultures of spores of $T$. Fraser $i$ in light after three days. In Fig. I3 (in tap-water) the spore has burst its exosporium (e.), but probably remains undivided, while in Fig. I4 (distilled water) the exosporium has been thrown off, and the young prothallus consists of three cells including a fairly long rhizoid. These specimens were grown in watchglasses with the water about $2 \mathrm{~mm}$. deep ${ }^{2}$. For the growth of the prothallus, distilled water has the advantage for some time, but in one experiment after fourteen days the prothalli in tap-water proved to have slightly outstripped those in distilled water as to length ${ }^{3}$. In distilled water the rhizoid is usually well developed.

Germination in 5 per cent. solution of cane-sugar gave slower growth of the prothallus than in tap-water, and the rhizoids were short.

A number of cultures were started in water in upright glass tubes $(4 \mathrm{~mm}$. diameter), but these need not be described further, as several of these

1 Rather hard water.

2 The rate of germination depends to some extent on the depth of the liquid, the relation being inverse.

3 This refers to the length of the prothallus, excluding the rhizoid. 
cultures were spoilt by Bacteria. In cultures made in watch-glasses, the spores and prothalli generally remained healthy for a long time. Bacteria sometimes appeared where a number of spores were crowded together, and the germination of these spores was thus prevented or checked; but, where the spores were more scattered, Bacteria were seldom to be seen. It should also be mentioned that a fungus, which Mr. G. Massee, F.L.S., kindly named for me as Dendryphium effusum, Bon., was sometimes found growing on the wall of the sporangium, both in cultures and on the living plants, but the presence or absence of the fungus appeared to have no effect on the germination of the spores in the sporangium.

Figs. I $^{-20}$ are given to show the characters or peculiarities of some young stages of prothalli. Figs. I 5 and 16 are two prothalli of T. hymenophylloides at the three-celled stage, showing different arrangement of the cells, Fig. I 5 being from a culture of spores in water in the dark, Fig. I 6 from a sporangium in light. Fig. 17 is a more advanced prothallus of the same species from a spore grown in water in the light. Figs. 18-20 are prothalli of $T$. Fraseri, Fig. I 9 being from a culture of spores on blottingpaper in darkness after thirty-three days. The cell marked with a cross contained very little chlorophyll. In cultures in the dark it was often noticed that the last-formed cell had scanty chlorophyll-grains, i. e. when the prothallus had reached a five- or six-celled stage. Under the conditions of the experiments it is probable that, at this stage, growth had nearly ceased, light being necessary for further development. Fig. I 8 is a prothallus grown on blotting-paper in the dark. The primary rhizoid-cell has not been formed, but a secondary rudimentary rhizoid is present. Fig. 20 is a prothallus from a similar culture to the last, and shows an unusual form with transverse growth.

In the germination of the spores of Todea Fraseriand T. hymenophylloides, there is some diversity in the arrangement of the cells of the young prothallus, but the commoner types agree well with the same stages in Osmunda cinnamomea and $O$. claytoniana as figured by Campbell, and Todea barbara as figured by Luerssen. Thus Figs. I4, 16, and I9 on Pl. XVI correspond with Campbell's Figs. I2 $a, 5$ and I4 ('92, Pl. III), and Luerssen's Figs. 6, 13, and I9 ('74, P1. XXIII). In rather later stages also the prothalli of the filmy species of Todea, while showing variation in breadth, \&c., reproduced several of the forms figured by Campbell and Luerssen in Osmunda and Todea, including occasional examples showing an early forking of the prothallus.

We may now return to a consideration of the results of the experiments. Free spores germinate normally, and produce prothalli of considerable size without forming antheridia ${ }^{1}$. Hence the production of dwarf male

1 At the conclusion of the experiments the largest prothalli consisted of more than twenty cells, but no antheridia had been formed. 
prothalli ${ }^{1}$ is not a character of the species, but proves to be connected with germination of spores in the closed sporangium. The conditions under which spores germinate in a sporangium probably differ in several respects from those under which a free spore germinates, e.g. as regards aeration, water supply, and supply of inorganic salts, but there are no data for estimating these factors ${ }^{2}$. One obvious difference, however, may be pointed out as probably important. The spores in the sporangium must germinate under pressure ${ }^{3}$, which must increase as more spores germinate. We may perhaps assume (I) that the pressure prevents the prothalli from growing to the size that they would attain if free, and (2) that the result of this will be the accumulation of certain organic food-substances, which would normally be used or diluted in connexion with growth. High concentration of these substances may cause special nutrition of the protoplasm, and this may lead to the precocious formation of antheridia ${ }^{4}$.

In experiments with Oedogonium Klebs ('96, p. 280) found that lack of nutritive salts (due to using only a small quantity of water for the culture) favoured the formation of sexual organs. In sporangia of Todea the spores may perhaps suffer from lack of salts owing to defective water-supply, but, that this factor alone will not explain the formation of dwarf male prothalli, is shown by the fact that free spores germinate normally in distilled water. The spores, moreover, probably contain a certain amount of inorganic reserves. Perhaps the most probable view for the spores of Todea is that any factor, which hinders growth without checking the accumulation of certain soluble organic food-substances, will favour the formation of sexual organs. External pressure (compression) would be one such factor, and severe scarcity of water ${ }^{5}$ would be another. The result of checking growth may be illustrated by another experiment of Klebs ('96, pp. 295-6). A species of Oedogonium, which grew in soft water, showed vigorcus formation of antheridia when transferred to an aquarium containing hard water, growth and division being much hindered in consequence of the amount of lime contained in the water.

In sporangia of Todea the absence of antheridia on the first-formed prothalli is perhaps explained by the pressure of the sporangial wall being still insufficient. The vegetative transformations of antheridia mentioned in the earlier part of this paper were observed in rather old cultures, and may

${ }^{1}$ In the present paper the term 'dwarf male prothalli' refers to extremely reduced forms comparable to Figs. 2 and 3.

${ }^{2}$ Hence any explanation must at present be a matter of pure speculation.

3 An attempt was made to imitate this condition by growing free spores in water and in gelatine under pressure supplied by a column of mercury, but the experiments failed; the control cultures showed that the conditions were unsatisfactory.

${ }^{4}$ It is possible, on the other hand, that conditions other than pressure in the sporangium may directly favour the formation of antheridia, and hinder growth as a secondary result.

${ }^{5}$ Drought has been given as one of the causes of precocious formation of antheridia on prothalli by Woronew ('94, p. 177) and others. 
have been due to a change in the conditions inside the sporangium, caused by the collapse of some of the prothalli, often observed in old cultures.

In many Ferns it is well known that, when spores are sown crowded, the prothalli remain small and produce antheridia only ${ }^{1}$. This is somewhat similar to the formation of dwarf male prothalli in Todea, but such extreme reduction of the prothallus as that shown by Todea has not often been observed. For the Osmundaceae, Luerssen ('74, p. 469) states that the antheridia often appear on very young prothalli, but in the only figure he gives of an antheridium on a complete prethallus the latter consists of twenty-six or more cells. Borodin ('68, p. 438) describes dwarf male prothalli in Allosurus; these will be referred to later. Schacht ('49, pp. 756, 787 , Taf. v, Fig. I) describes extremely small prothalli bearing antheridia in Pteris serrulata ${ }^{2}$, and his figure shows a case in which only an antheridium and two other cells are present, viz. a short cell containing chlorophyll, and a rather well-developed primary rhizoid. Cornu (74, p. I6I) describes similar prothalli (of two cells and an antheridium) in Nephrodium Filix-mas. In these two cases the degree of reduction is similar to that found in Todea. Woronew ('94, p. I77) also describes the formation of antheridia on reduced prothalli (of three or four cells) under unfavourable cultural conditions.

Regarding the power of Fern-spores to germinate in the dark, the earlier statements are contradictory. Thus Borodin ('68, p. 432) and Kny (' 72, p. 4) described light as necessary for germination, while Schelting (75, p. 328), experimenting with spores of four species of Anemia, Pteris, and Aspidium, found that they all germinated in the dark. Beck ('78, p. 780 ), however, found that spores of Scolopendrium vulgare would only germinate in the light, and Woronew ('94, p. I76) failed to germinate spores of ordinary Ferns in darkness, but succeeded with those of Pilularia and Marsilia. Heald ('98, p. 43) found that in Ceratopteris thalictroides the spores refused to germinate in the dark at a temperature of $19^{\circ}$ to $2 \mathrm{I}^{\circ} \mathrm{C}$, though germinating in light at this temperature, but that at $32^{\circ} \mathrm{C}$. they germinated well in darkness. He regards the conflicting results of earlier authors as probably explained by assuming that unsuitable temperatures were used in some of their experiments. Heald only experimented with one species of Ceratopteris and one of Alsophila, hence it is unsafe to

${ }^{1}$ Goebel ('82, p. 198). Millardet ('69, p. 50), referring to prothalli bearing antheridia only, states that in one entire sowing of Osmunda regalis he could not find a single archegonium. Prantl ('78, p. 499) found that the production of archegonia was connected with meristematic growth of the prothallus, inasmuch as reduced prothalli with no meristem (' ameristic prothalli') bore antheridia, but never archegonia. He attributes the ameristic condition to insufficient nutrition, light or water (and especially the dissolved mineral salts), but sometimes refers it to the nature of the spore itself. In a later paper Prantl ('81, p. 753) showed that absence of nitrates in the nutrient solution conduced to the formation of ameristic prothalli. Sadebeck $(79, \mathrm{p} .166)$ points out that the tendency to dioecism ascribed to Ferns is explained in most cases by the fact that certain prothalli have remained ameristic.

${ }^{2}$ In this species dwarf prothalli bearing antheridia are also described by Atkinson ('94, pp. 15, 16). 
generalize from his results, but his determination of the influence of temperature is important. Since the publication of Heald's work, other papers dealing with the same subject have appeared. Burgerstein ('01, p. 92) found light necessary to germination. Schulz ('02, p. 97) experimented with several Ferns, and found that the spores only germinated in the light, except in the case of Ceratopteris thalictroides, Hydropterideae and Ophioglossaceae. Life ('07, p. I $2 \mathrm{I}$ ) did not succeed in germinating Fern-spores in the dark, even when the temperature was $30^{\circ}$ to $33^{\circ} \mathrm{C}$. In his experiments the spores were sown on leaf-mould. Laage ('07, p. III, \&c.) made numerous experiments, using Knop-solution ( $\mathrm{I}$ per cent. and other strengths) and several other liquids. In darkness he obtained germination of spores of Osmunda regalis, Pteris aquilina, Scolopendrium officinale (S. vulgare, Sm.), Aspidium aculeatum, and A. Filix-mas, but failed with Asplenium lucidum, Alsophila australis, and Polypodium aureum.

From a consideration of these numerous researches, which in one or two cases gave opposite results for the same species, it appears very probable that the failure of spores to germinate in the dark was due in some cases to an unfavourable temperature. With the most suitable medium and temperature (both of which may vary for different species) it is possible that most or perhaps all Fern-spores might be capable of germination in the dark; but this remains to be seen.

In Todea Fraseri germination took place in the dark in tap-water between $60^{\circ}$ and $70^{\circ} \mathrm{F}$. $\left(16^{\circ}-21^{\circ} \mathrm{C}\right.$.), but neither the optimum temperature nor the best medium was ascertained. The nutrition of the spores, when germinating in darkness, is apparently provided by a reserve of an oily substance ${ }^{1}$. Spores were crushed in I per cent. solution of osmic acid, and it was found that oil was more abundant in $T$. Fraseri than in $T$. hymenophylloides. This may explain the greater readiness with which spores of the former species germinate, which is specially noticeable in darkness. The oil is probably partially converted into a soluble carbohydrate (see previous foot-note), which supplies the osmotic strength of the cell-sap necessary for germination. Definite limits of temperature for germination in this and other species of Ferns are probably fixed by those necessary for the action or formation of an enzyme, which converts the oil into a soluble carbohydrate and other bodies. ${ }^{2}$

1 Borodin ('68, p. 446) states that, on the germination of Fern-spores in the light, the oil appears to be transformed into starch. Schulz $(02, \mathrm{pp} .90,93)$ observed the presence of oil in Fern-spores, and found in Aspidium, \&c. (which he did not succeed in germinating in darkness), that the formation of starch began with germination in light. He obtained the same result with Ceratopteris in darkness. This probably indicates that a sugar is formed, and that, when it reaches its maximum concentration, germination begins.

${ }^{2}$ The physiological process may be quite similar to that described by Green (' 90, p. $3^{8} 4$, sez also Czapek, '05, vol. i, p. I 29 et seq.) in the endosperm of Ricinus, the reserve-oil being split up by an enzyme (lipase, formed from a lipozymogen present in the resting spore) into a fatty acid and glycerine, and the glycerine being at once converted into sugar. 
For examples of intrasporangial germination in other Ferns we may quote the case of the Hymenophyllaceae, in which the spores sometimes undergo the first few divisions in the closed sporangia (Sadebeck, '79, p. I 59). It is also interesting to recall a case described by Scott ('04, p. I 8) of germinating spores in a fossil Fern-sporangium, especially as the specimen appears to be allied to the Osmundaceae. Here, however, the wall of the sporangium is broken, and it is uncertain whether dehiscence may have taken place before the germination of the spores. It may be a similar occurrence to that described in Todea hymenophylloides (Boodle, '00, p. 484), viz. the germination of spores in a ruptured sporangium, when dehiscence has been weak, so as only to eject a few of the spores, and probably this is also the explanation of the case figured by Atkinson ('94, p. 7, Fig. I2) in Pteris serrulata. In a second case described by Scott ('06, p. 170, Fig. 27) in a fossil Fern, the germination may well have taken place in the closed sporangium.

Borodin ('68, p. 438) states that he obtained a certain number of dwarf male prothalli by sowing spores of Allosurus sagittatus in water in the light, and transferring them into darkness after $5^{-6}$ days (i. e. just when germination was beginning). The culture afterwards showed that most of the spores had remained unchanged, but that a certain number had produced dwarf gametophytes. The prothallus was reduced to a single cell, and bore from one to three antheridia. It is just possible that these reduced prothalli, and some of those described by Schacht and others, may have really been produced by previous germination in the sporangia from which the spores were taken for sowing.

The fact that in filmy species of Todea a certain degree of dampness can, by preventing dehiscence of the sporangium ${ }^{1}$, cause extreme reduction of the gametophyte, comparable to that shown by Salvinia and Azolla (in the male prothallus), is of considerable interest, as showing how easily such reduction may be brought about in relation to external conditions. It will be important to learn whether Todea barbara, Moore, which is not a filmy species, would behave in the same way, and what result would be obtained by placing the sporangia of other Ferns under various conditions. It is possible that a study of this subject may yield information bearing on reduction of the gametophyte in other phyla besides the Filicineae.

\section{SUMMARY.}

When plants of Todea Fraseri are kept in a sufficiently damp atmosphere, the sporangia do not dehisce, and a number of spores germinate in the closed sporangia. In drier air the sporangia dehisce normally.

1 It would be interesting to know whether dehiscence of the sporangium is ever prevented by dampness in the natural habitats of these species. 
When a considerable number of spores germinate in the sporangium, some of the prothalli (apparently not those first formed) produce antheridia. Usually a single antheridium is borne terminally on a prothallus of only three or four cells (occasionally of one or two cells), and in these specimens the rhizoid is generally not developed.

Sporangia, whether detached, or attached to a pinnule or pinna, behave similarly to those attached to the living plant. If kept sufficiently damp to prevent dehiscence (and with other conditions favourable), intrasporangial germination takes place, and prothalli bearing antheridia are ultimately formed. Antheridia were found in one experiment after twenty-one days. The prothalli do not appear to be capable of bursting the wall of the sporangium, and ultimately die. Motile spermatozoids were not seen, but once or twice the bursting of the antheridium and the emission of the sperm-cells were observed.

Free spores, placed under the same conditions as the sporangia, never produced dwarf male prothalli, but formed normal prothalli, which had not developed sexual organs at the conclusion of the experiments.

Free spores germinate in the dark in tap-water at the temperature of the experiments (roughly between $16^{\circ}$ and $21^{\circ} \mathrm{C}$.), and the prothallus may at any rate reach a six- or seven-celled stage. Spores also germinate in the closed sporangium in the dark, and under favourable conditions dwarf prothalli with antheridia are produced.

In Todea hymenophylloides the spores germinate less readily than in T. Fraseri. This may be due to the smaller amount of oil present in the spores of the former species. In $T$. hymenophylloides prothalli bearing antheridia were found in closed sporangia in only one or two experiments; they were not seen in sporangia on the living plant, though germination of a few spores was observed several times. As in T. Fraseri, free spores always produced normal prothalli. In $T$. Moorei and $T$. superba slight germination of spores in the sporangium was observed, but these species were not used in experiments.

A possible explanation of the formation of dwarf male prothalli in the sporangium is suggested. The mechanical hindrance to the growth of the prothalli caused by the pressure of the wall of the sporangium probably causes concentration of certain organic food substances. This may lead to special nutrition of the protoplasm, and this again may cause the precocious formation of sexual organs. Scarcity of water in the sporangium may perhaps have a similar influence.

\section{LITERATURE REFERRED TO.}

Atkinson ('94): The Study of the Biology of Ferns by the Collodion Method, New York.

BECK (78): Entwickelungsgeschichte des Prothalliums von Scolopendrium vulgare. Bot. Zeitung, Jahrg. 36, p. 780 . 
Boodle ('00): Anatomy of the Hymenophyllaceae. Annals of Botany, vol. xiv, p. 455.

Borodin ('68): Ueber die Wirkung des Lichtes auf einige höhere Kryptogamen. Bull, de l'Acad. Imp. d. sc. de St. Pétersbourg., vol. xii, r868, p. $43^{2}$.

Burgerstein ('01) : Keimen Farnsporen bei Lichtabschluss? Wiener illustr. Gartenzeitung, Jahrg. 26, p. 92.

CAm Pbell ('92): On the Prothallium and Embryo of Osmunda claytoniana, L., and O. cinnamomea,

L. Annals of Botany, vol. vi, p. 49.

Cornu ('74): Bull. de la Soc. Bot. de France, vol. xxi, p. I6I.

Czapek ('05): Biochemie der Pflanzen.

Goebel ('82): Outlines of Classification; English edition, I887.

Green ('90): On the Changes in the Endosperm of Ricinus communis during Germination. Annals of Botany, vol. iv, p. $3^{8} 3$.

Heald ('98): Conditions for the Germination of the Spores of Bryophytes and Pteridophytes. Bot. Gazette, vol. xxvi, p. 25.

Heim ('96): Untersuchungen über Farnprothallien. Flora, Bd. 82, p. 329.

KLebs ('96): Die Bedingungen der Fortpflanzung bei einigen Algen und Pilzen, Jena.

KNY ('72): Beiträge zur Entwickelungsgeschichte der Farrnkräuter ; I. Entwickelung des Vorkeimes von Osmunda regalis, L. Pringsheim's Jahrb., vol. viii, p. I.

LAAGE ('07): Bedingungen der Keimung von Farn- und Moos-sporen. Beihefte zum Bot. Centralblatt, vol. xxi, Abt. I, p. 76 .

LifE ('07): Effect of Light upon the Germination of Spores and the Gametophyte of Ferns Eighteenth Annual Report of the Missouri Botanical Garden, St. Louis, I907, p. Io9.

Luerssen ('74): Zur Keimungsgeschichte der Osmundaceen, vorzïglich der Gattung Todea, Willd. Schenk und Luerssen's Mittheil. aus d. Gesammtgebiete der Botanik, Bd. I, p. 46o.

Millardet ('69) : Le prothallium mâle des Cryptogames Vasculaires, Strasbourg.

Prantl ('78): Ueber die Anordnung der Zellen in flächenförmigen Prothallien der Farne. Flora, Jahrg. 36 , p. 497 .

('81): Berbachtungen über die Ernährung der Farnprothallien und die Verteilung der Sexualorgane. Bot. Zeitung, Jahrg. 39, p. 753 .

SAdebeck (' 19 ): Die Gefässkryptogamen. Schenk, Handbuch der Botanik, p. I 48.

Sснаснт ('49): Beitrag zur Entwickelungsgeschichte der Farrnkräuter. Linnaea, vol, vi, p. 753.

Schelting ('75): Einige Fragen betreffend die Entwickelungsgeschichte der Farnkräutervorkeime. Schriften der kais. Neuruss. Univ. in Odessa, Bd. xvii. Abstract, Bot. Jahresbericht, vol. iii, $1875, \mathrm{p} .328$.

Schulz ('02): Ueber die Einwirkung des Lichtes auf die Keimungstähigkeit der Sporen der Moose, Farne und Schachtelhalme. Beihefte zum Bot. Centralblatt, vol. xi, p. 8I.

ScotT ('04) : Germinating spores in a fossil Fern-sporangium. New Phytologist, vol. iii, p. I 8.

('06): The Occurrence of Germinating Spores in Stauropteris oldhamia. New Phytologist, vol. v, p. I 70 .

Woronew ('94): Ueber den Einfluss der äusseren Bedingungen auf die Entwickelung des Vorkeimes der Farne. Uebersicht d. Leistungen a. d. Geb. d. Bot. in Russland während d. Jahres I 892. Petersburg, I 894. Abstract, Bot. Jahresbericht, I 894, p. I 76.

\section{EXPLANATION OF PLATE XVI.}

Illustrating Mr. Boodle's paper on Dwarf Male Prothalli in Todea.

Lettering used in several figures: e., exosporium; a., cavity of antheridium; r.c., rhizoid-cell ; $r$., rhizoid; s., sperm-cells.

Figs. I-7. Todea Fraseri.

Fig. I. Microtome-section through a closed sporangium, showing germinated spores cut in different directions; eight antheridia are visible. $\times 90$.

Fig. 2. Section of one germinated spore from the same sporangium. The antheridium at the top contains sperm-cells, and is borne by the dwarf prothallus, the base of which is enclosed by the ruptured exosporium. $\times 390$. 
Fig. 3. Prothallus with antheridium from a closed sporangium, exposed to daylight, after 21 days; a rhizoid-cell is present. $\times 260$.

Fig. 4. Data as in last. There is no rhizoid-cell, but the rudiment of a lateral branch $(l$.$) has$ been formed. $\times 260$.

Fig. 5. Prothallus (enclosed by exosporium) and antheridium from a closed sporangium; darkness, 26 days. $\times 260$.

Fig. 6. Prothallus grown from a free spore on damp blotting-paper; darkness, 26 days. $\times 260$.

Fig. 7. Small antheridium borne by two prothallial cells, one of which probably represents the stalk of the antheridium. From a closed sporangium; darkness, 22 days. $\times 260$.

Fig. 8. T. hymenophylloides. Small prothallus with antheridium (containing chlorophyll). From a sporangium; daylight, $3^{2}$ days. $\times 260$.

Fig. 9. T. hymenophylloides. Prothallus from a sporangium; daylight, 32 days. $\times 260$.

Fig. Io. T. hymenophylloides. Prothallus from a sporangium; daylight, 45 days. The upper cells probably represent an abortive antheridium. $\times 260$.

Fig. II. T. Fraseri. Prothallus from a free spore on damp blotting-paper; daylight, 36 days. $\times 260$.

Fig. I 2. T. hymenophylloides. Prothallus from a free spore on damp blotting-paper; daylight, 32 days. $\times 260$.

Fig. I3. T. Fraseri. Spore germinating in tap-water; daylight, 3 days. $\times 260$.

Fig. 14. T. Fraseri. Young prothallus from a spore in distilled water; daylight, 3 days. $\times 260$.

Fig. I5. T. hymenophylloides. Young prothallus from a spore in water; darkness, 25 days. $\times 390$.

Fig. 16. T. hymenophylloides. Young prothallus from a spore in a sporangium attached to a pinna on damp blotting-paper; daylight, I 3 days. $\times 390$.

Fig. I 7. T. hymenophylloides. Prothallus from a spore in water; daylight, 19 days. $\times 390$.

Figs. 18-20. T. Fraseri. Prothalli from spores on damp blotting-paper; darkness, 33 days. $\times 260$. 
Annals of Botany,

Vol. XXII, PL.XVI.
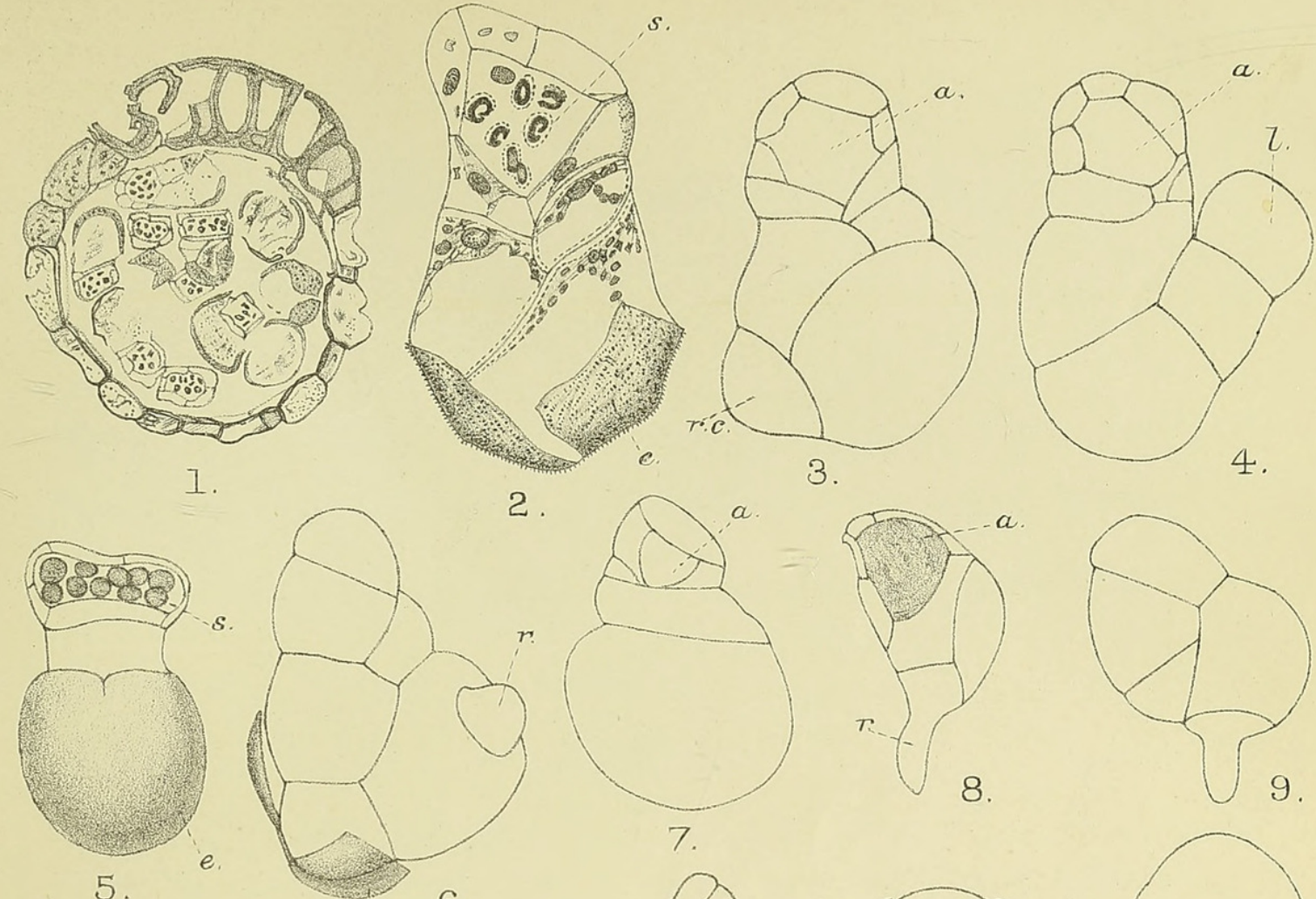

2 .
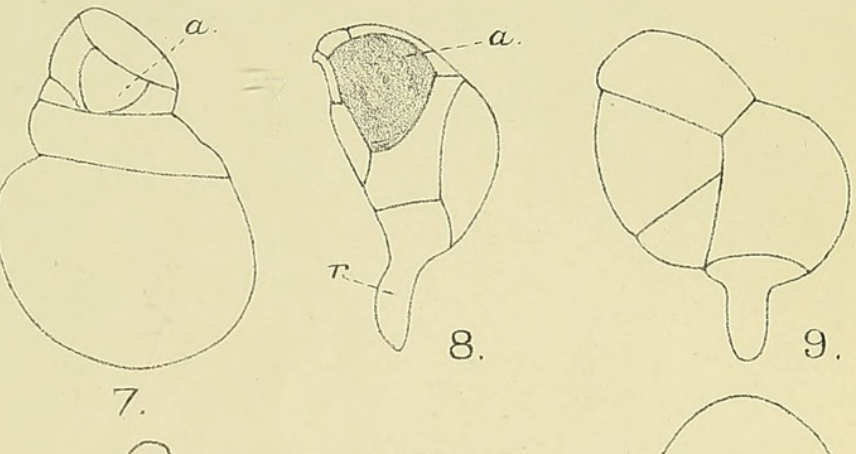

5
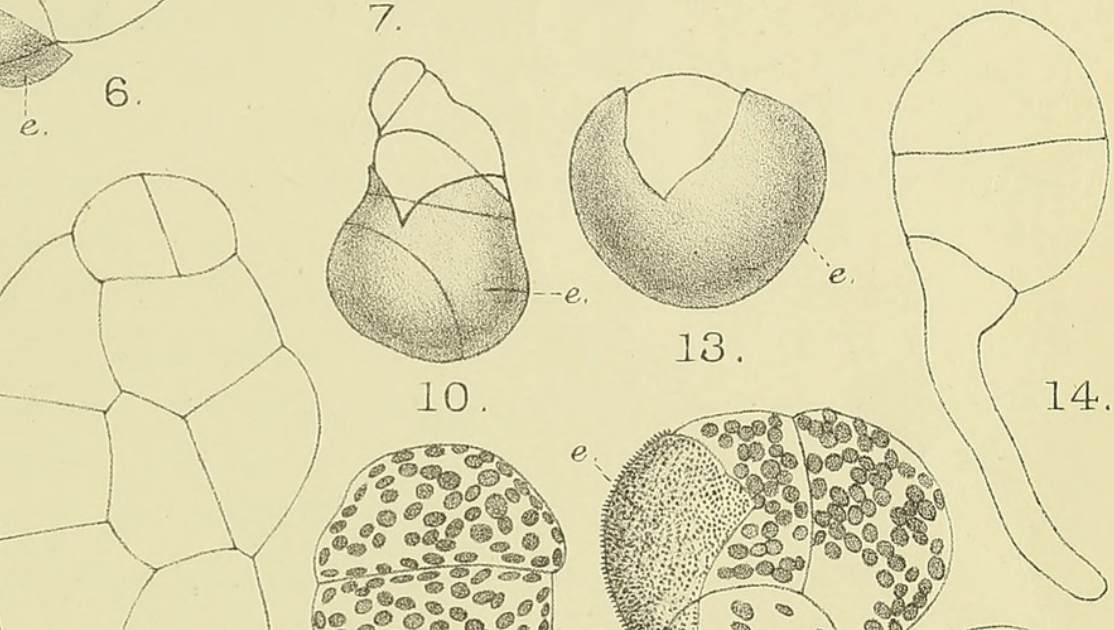

10

14.
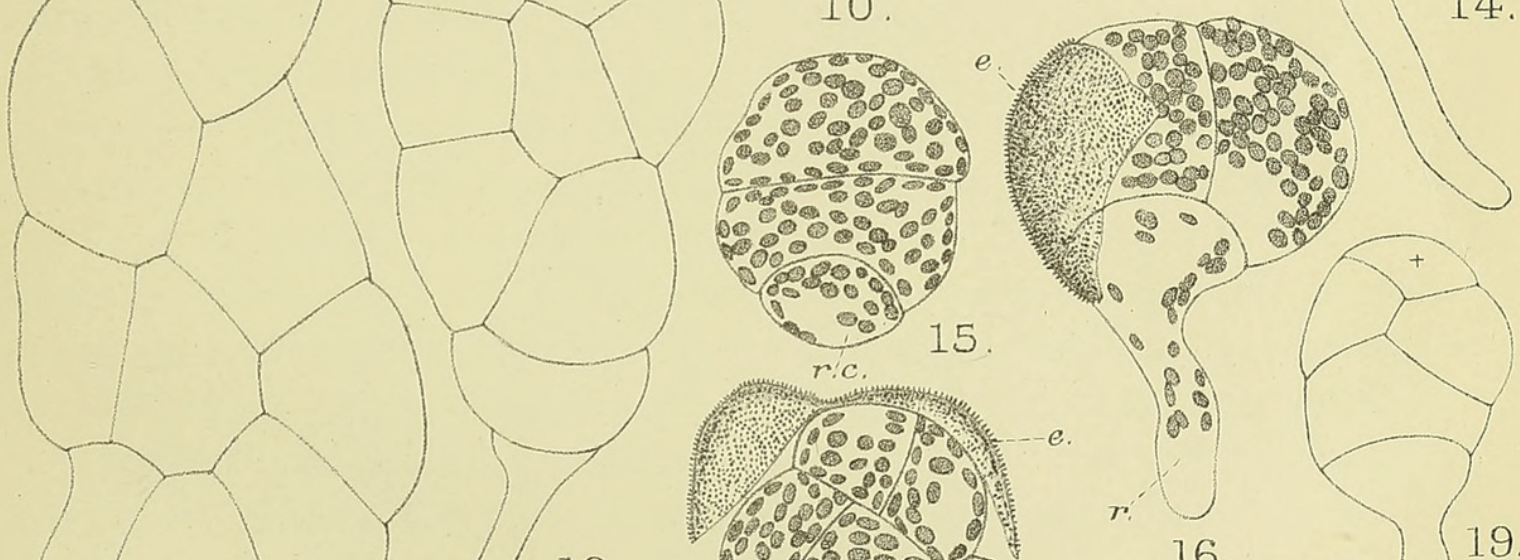

$10.90 \%$

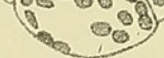

15
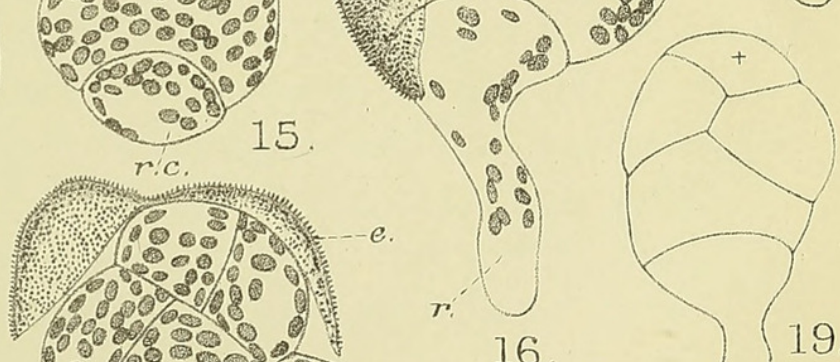

-

$8:$

12.

$\therefore \%{ }^{\circ} \cdot{ }^{\circ}$

16

11.

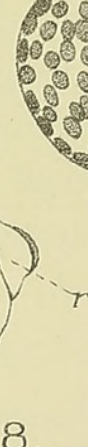

18.
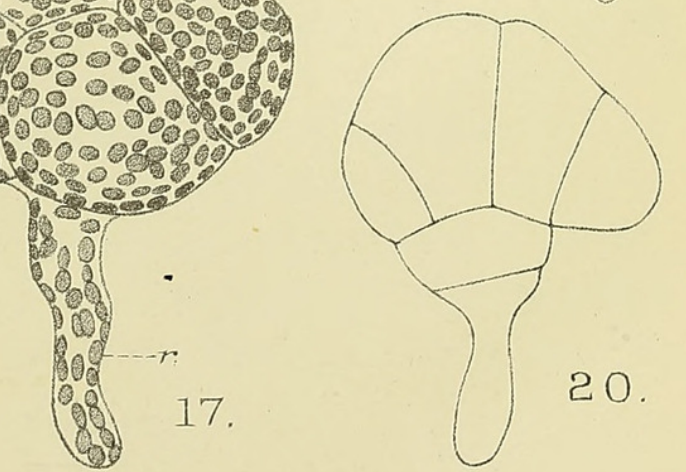


\section{$2 \mathrm{BHL}$ Biodiversity Heritage Library}

Boodle, Leonard Alfred. 1908. "On the production of dwarf male prothalli in Sporangia of todea." Annals of botany 22, 231-243.

https://doi.org/10.1093/oxfordjournals.aob.a089169.

View This Item Online: https://www.biodiversitylibrary.org/item/232525

DOI: https://doi.org/10.1093/oxfordjournals.aob.a089169

Permalink: https://www.biodiversitylibrary.org/partpdf/318905

\section{Holding Institution}

Smithsonian Libraries

\section{Sponsored by}

Biodiversity Heritage Library

\section{Copyright \& Reuse}

Copyright Status: Not in copyright. The BHL knows of no copyright restrictions on this item.

This document was created from content at the Biodiversity Heritage Library, the world's largest open access digital library for biodiversity literature and archives. Visit BHL at https://www.biodiversitylibrary.org. 